\title{
Leukemia mortality trends among children, adolescents, and young adults in Latin America
}

\author{
Maria Paula Curado, ${ }^{1}$ Thais Pontes, ${ }^{1,2}$ Marta E. Guerra-Yi, ${ }^{1}$ \\ and Marianna de Camargo Cancela ${ }^{1,3}$
}

Suggested citation Curado MP, Pontes T, Guerra-Yi ME, de Camargo Cancela M. Leukemia mortality trends in children adolescents, and young adults in Latin America. Rev Panam Salud Publica. 2011;29(2):96-102.

ABSTRACT Objective. To describe and compare trends in leukemia mortality among children (0-14 years of age) and adolescents and young adults ( $A Y A, 15-24$ years of age) in 12 countries in Latin America during 1980-2004.

Methods. Data from the World Health Organization mortality database was analyzed using a joinpoint regression model to identify significant mortality rate changes over time and to estimate annual percent change.

Results. Leukemia is ranked first among cancer-related causes of death among children and AYA in Latin America. In children, the global percentage changes indicate increased rates for both sexes in Colombia, Ecuador, and Mexico, with substantially higher rates for Mexico. In AYA, significant increases were observed for both sexes in Mexico; Ecuador saw some increase for both sexes; and Colombia and Uruguay had increases in females only. Downward trends were observed in Argentina for both sexes, and in Costa Rica for males only. There were no major changes in the other countries analyzed.

Conclusions. Leukemia mortality rates among AYA are declining, but show less significant decreases than rates among children. The study results point to a global need for further advances, specifically for AYA, similar to those made by childhood leukemia therapeutic protocols. Also, specialized oncological centers exist in most countries of Latin America, but they are often inaccessible. Special attention should be given to Mexico due to the significant increase in mortality rates.

Key words Leukemia; child; young adult; adolescent; Latin America.

The 21 countries that compose Latin America-from Mexico to Argentina, including Cuba and the Dominican Republic - have a total population of more

International Agency for Research on Cancer, Cancer Information Section, Lyon, France. Send correspondence to Maria Paula Curado, maria-paula.curado@i-pri.org

2 Universidade Federal do Rio de Janeiro, Faculdade de Medicina, Rio de Janeiro, Brazil.

3 Université de Lyon, Claude Bernard Lyon 1, Ecole Doctorale Interdisciplinaire Sciences-Santé, Lyon, France. than 500 million. Despite economic and social growth in recent decades, inequality and poverty continue to be the area's main challenges (1). One aspect of inequality and poverty in Latin America is unequal access to basic infrastructure.

Describing cancer among a population is a complex task involving indicators such as incidence, survival, prevalence, and mortality. These indicators are related to each other, and any change in one of them necessarily affects the oth- ers. Therefore, cancer-specific mortality rates are changing dramatically worldwide as cancer survival increases. Childhood cancer mortality rates are well documented and, in developed areas of the world, have shown substantial declines since the early 1960s. Favorable trends began later on and were less pronounced in the less developed areas of the world, including Latin America (2). However, there is far less data available regarding cancer mortality among adolescents and 
young adults (AYA), those 15-24 years of age.

Leukemia therapeutic protocols have been very well established and important improvements have been seen in recent decades, including a 5-year survival rate for children and adolescents $(<19$ years of age) of $84 \%$ (3). However, leukemia prognosis for AYA, while improving over the last 30 years, did not decline as much as children's rates (4).

At the global level, the number of persons 15-24 years of age is increasing at an all time high of nearly 1.2 billion annually; this number is not expected to decline before 2050. Nearly 9 of every 10 individuals 15-24 years of age live in the developing world, including Latin America (5). Therefore, improvements for cancer treatment services and aftercare for AYA is necessary. However, the planning of services for this group requires detailed population-based data that are not widely available.

In Latin America, the leading cancerrelated cause of death for the AYA age group (15-24 years of age) is leukemia (6). Other cancer diagnoses, such as some solid tumors (brain, bone, and kidney tumors) are also prevalent in AYA; however, these pathologies have not shown important changes in their therapeutic protocols (such as new multidrug protocols), and prognosis for children and AYA, as well as survival rates, remain stable. It was, therefore, of interest to conduct an updated analysis specifically for leukemia mortality data in Latin America for this particular age group.

There are no clear definitions of "adolescents" and "young adults" in the literature-the age range for this population varies from one study to another. This study focused on the group 15-24 years of age because it is often overlooked in cancer control activities, and also because most of the recent studies on AYA used this age range.

Annual mortality data were not available for all Latin American countries; hence, the study includes mortality trends for only 12 of the 21 countries. The aim was to describe leukemia mortality trends in children less than 15 years of age and AYA in 12 countries of Latin America during the 25-year period from 1980-2004. These 12 countries, the study's population sample, represent $87.1 \%$ of the population of Latin America, including nearly 200 million in the age group 15-24 years of age.

\section{MATERIALS AND METHODS}

Official certified deaths from leukemia for the period 1980-2004 for the 12 countries were obtained from the World Health Organization (WHO) Mortality Database, current as of July 2008 (7). Data consisted of the number of deaths by country, by calendar year, and by sex per 5-year age group.

Countries were selected according to the completeness of their mortality data. Of the 21 countries, Argentina, Brazil, Chile, Costa Rica, Cuba, Ecuador, and Mexico had complete annual data for 1980-2004; Colombia started its registries in 1984, but had 2 years missing since that year; the Dominican Republic and Paraguay had 2 years missing as well; and Uruguay and Venezuela had 3 years missing. However, this did not interfere with the reliability of data. The remaining eight countries had either very incomplete data or none at all, and for that reason were excluded from the study.

During the study period, 1980-2004, two revisions of the International Classification of Diseases (ICD-9 and ICD-10) were used $(8,9)$; therefore, the study data included codes 1045 (C91-C95, ICD-10) and B141 (204-208, ICD-9), which correspond to the underlying cause of death as "Leukemia," with no distinction by Leukemia subtypes (all leukemias pooled).

Annual estimates of the population, by 5-year age-groups and by sex, were obtained from United Nations Population Division (10). Mortality and population data were merged, and for each country, the 5-year age-specific mortality rates, the overall age-standardized rates per 100000 males/females, and rates truncated to 0-14 years of age and 15-24 years of age were computed by gender and calendar year (annually), as well as for the periods 1980-1984, 1990-1994, 1995-1999, and 2000-2004. The direct standardization method was used with the world standard population as defined by Segi (11). In order to describe the occurrence of significant changes in mortality rate trends, a joinpoint regression model was used (12). This technique permits the identification of the calendar years in which a significant variation in trends has occurred (the "joinpoints"). In other words, it selects the best-fitting points where the rate changes significantly, either by increasing or decreasing.
The statistics derived from these models are the annual percentage change (APC) in the rates associated with each line segment, the confidence intervals (CI) for the APC, and the joinpoints (calendar years) at which there is a change in trend. This analysis was conducted with the Joinpoint Regression Program, version 3.3.1 (National Cancer Institute, Bethesda, Maryland, United States of America) and STATA, version 10.0 (Stata Corporation, College Station, Texas, United States).

\section{RESULTS}

The highest leukemia mortality rates during 2000-2004 were found in Mexico and Ecuador for children and AYA of both sexes (Figure 1).

Tables 1 and 2 show the number of deaths and age-standardized leukemia mortality rates among males and females in the age groups 0-14 years of age and 15-24 years of age, respectively, in the 12 study countries for three 5-year periods (1980-1984, 1990-1994, and 2000-2004), as well as the global percentage change and the male:female ratio calculated from the average number of cases in each sex.

For children, the global percentage changes from the period 1980-1984 to 2000-2004 indicate increased rates for both sexes in Colombia, Ecuador, and Mexico, with substantially higher rates for Mexico.

For AYA, an increase can be observed for both sexes in Ecuador and Mexico, with higher rates for males (Table 2). Paraguay showed an increased rate for males only, while Colombia, Uruguay, and Venezuela showed increased rates for females only. For children, the highest global percentage change was observed for females in Mexico (+20.9\%), while for AYA, males in Ecuador $(+32.7 \%)$ had the highest global percentage. All the other countries had a downward global percentage change, the lowest being for female children in Uruguay $(-63.6 \%)$ and male AYA in Costa Rica $(-40.9 \%)$. The male:female ratio indicates higher rates for males than for females in all countries for children and AYA, except for AYA in Uruguay (+0.8).

Tables 3 and 4 show results of the joinpoint analysis of leukemia mortality rates during 1980-2004, by gender, truncated to 0-14 years of age and 15-24 years of age, respectively, for the 12 study countries. 
FIGURE 1. Leukemia mortality rates truncated to 0-14 years of age and 15-24 years of age, by gender, in 12 countries of Latin America, with the available data from 2000-2004



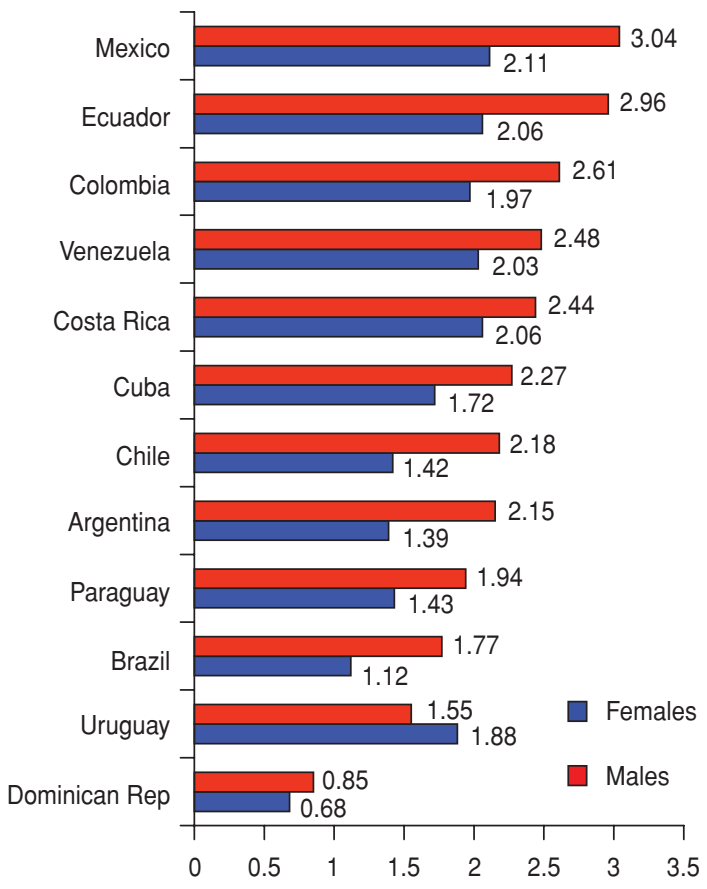

Adolescents and young adults (15-24 years of age)

TABLE 1. Truncated rates, average number of cases, global \% change, and male to female ratios of leukemia mortality for both sexes in the agegroup 0-14 years of age in 12 countries of Latin America, 1980-2004

\begin{tabular}{|c|c|c|c|c|c|c|c|c|c|c|c|}
\hline & \multicolumn{5}{|c|}{ Males } & \multicolumn{5}{|c|}{ Females } & \multirow[b]{2}{*}{$\begin{array}{c}\text { Male to } \\
\text { female ratio } \\
2000- \\
2004 \\
\text { (cases) }^{b}\end{array}$} \\
\hline & $\begin{array}{c}1980- \\
1984 \\
T^{a}\end{array}$ & $\begin{array}{c}1990- \\
1994 \\
\text { TR }\end{array}$ & $\begin{array}{c}2000- \\
2004 \\
\text { TR }\end{array}$ & $\begin{array}{l}\text { Average } \\
\text { number } \\
\text { of deaths } \\
(2000- \\
2004)\end{array}$ & $\begin{array}{c}\text { Global } \\
\% \\
\text { change }\end{array}$ & $\begin{array}{c}1980- \\
1984 \\
\text { TR }^{a}\end{array}$ & $\begin{array}{c}1990- \\
1994 \\
\text { TR }\end{array}$ & $\begin{array}{c}2000- \\
2004 \\
\text { TR }\end{array}$ & $\begin{array}{l}\text { Average } \\
\text { number } \\
\text { of deaths } \\
(2000- \\
2004)\end{array}$ & $\begin{array}{c}\text { Global } \\
\% \\
\text { change }\end{array}$ & \\
\hline Argentina & 6.19 & 4.22 & 3.10 & 89.00 & -49.92 & 4.41 & 3.02 & 2.68 & 74.00 & -39.23 & 1.20 \\
\hline Brazil & 3.32 & 2.70 & 2.67 & 387.00 & -19.58 & 2.61 & 2.22 & 2.32 & 319.00 & -11.11 & 1.21 \\
\hline Chile & 4.59 & 4.05 & 2.88 & 34.00 & -37.25 & 4.17 & 3.20 & 2.31 & 27.00 & -44.6 & 1.26 \\
\hline Colombia ${ }^{c}$ & 4.00 & 4.17 & 4.10 & 157.00 & 2.50 & 3.47 & 3.90 & 3.58 & 129.00 & 3.17 & 1.22 \\
\hline Costa Rica & 5.40 & 4.27 & 3.28 & 11.00 & -39.26 & 5.90 & 3.77 & 2.33 & 8.00 & -60.51 & 1.38 \\
\hline Cuba & 4.54 & 4.07 & 4.34 & 27.00 & -4.41 & 3.98 & 3.16 & 2.96 & 17.00 & -25.63 & 1.59 \\
\hline Dominican Republic ${ }^{d}$ & 2.39 & 1.39 & 1.43 & 13.00 & -40.17 & 1.76 & 1.30 & 1.09 & 9.00 & -38.07 & 1.44 \\
\hline Ecuador & 4.23 & 4.52 & 4.38 & 52.00 & 3.55 & 3.62 & 4.06 & 3.93 & 45.00 & 8.56 & 1.16 \\
\hline Mexico & 4.43 & 4.40 & 5.28 & 486.00 & 19.19 & 3.67 & 3.77 & 4.44 & 392.00 & 20.98 & 1.24 \\
\hline Paraguaye & 2.91 & 3.43 & 2.84 & 17.00 & -2.41 & 1.76 & 2.17 & 2.25 & 13.00 & 27.84 & 1.31 \\
\hline Uruguay $^{f}$ & 6.42 & 3.40 & 2.73 & 6.00 & -57.48 & 3.79 & 3.17 & 1.38 & 3.00 & -63.59 & 2.00 \\
\hline Venezuelag & 4.63 & 4.63 & 4.36 & 100.00 & -5.83 & 4.08 & 4.10 & 3.50 & 78.00 & -14.22 & 1.29 \\
\hline
\end{tabular}

a TR: Truncated rates to $0-14$ years-old.

${ }^{b}$ Male to female ratio calculated from the average number of cases per sex in 2000-2004.

c No data for 6 years: $1980-1984,2002$, and 2003 .

d No data for 2 years: 1993 and 2002.

e No data for 2 years: 1992 and 1993.

f No data for 3 years: 1991, 1992, and 2002.

g No data for 3 years: 1984,1991 , and 1995.

For children, mortality rates increased significantly in Mexico for both genders: males showed three trends, with the highest increase in 1980-1987 $(+3.31 \%$ annually; $95 \%$ Confidence Interval $(\mathrm{CI})=1.68-$
4.96), while females had only one trend (+0.90 annually; $95 \% \mathrm{CI}=0.56-1.24)$; and in Paraguay, for males only: with two trends and the highest rates in 1980-1998 $(+2.07 \%$ annually; $95 \% \mathrm{CI}=0.40-3.76)$.
However, significant downward trends could be observed in most countries studied for both genders (ranging from $-4.55 \%$ annually for males in Uruguay to $-0.89 \%$ annually for females in Venezuela). 
TABLE 2. Truncated rates, average number of cases, global \% change, and male to female ratios of leukemia mortality for both sexes in the agegroup 15-24 years of age in 12 countries of Latin America, 1980-2004

\begin{tabular}{|c|c|c|c|c|c|c|c|c|c|c|c|}
\hline & \multicolumn{5}{|c|}{ Males } & \multicolumn{5}{|c|}{ Females } & \multirow[b]{2}{*}{$\begin{array}{c}\text { Ratio M/F } \\
2000- \\
2004 \\
\text { (cases) }^{b}\end{array}$} \\
\hline & $\begin{array}{c}1980- \\
1984 \\
\operatorname{ASR}(W)^{a}\end{array}$ & $\begin{array}{c}1990- \\
1994 \\
\text { ASR(W) }\end{array}$ & $\begin{array}{c}2000- \\
2004 \\
\text { ASR(W) }\end{array}$ & $\begin{array}{c}\text { Number } \\
\text { of } \\
\text { deaths } \\
(2000- \\
2004)\end{array}$ & $\begin{array}{c}\text { Global } \\
\% \\
\text { change }\end{array}$ & $\begin{array}{c}1980- \\
1984 \\
\text { ASR(W) }\end{array}$ & $\begin{array}{c}1990- \\
1994 \\
\text { ASR(W) }\end{array}$ & $\begin{array}{c}2000- \\
2004 \\
\text { ASR(W) }\end{array}$ & $\begin{array}{c}\text { Number } \\
\text { of } \\
\text { deaths } \\
(2000- \\
2004)\end{array}$ & $\begin{array}{c}\text { Global } \\
\% \\
\text { change }\end{array}$ & \\
\hline Argentina & 2.64 & 2.06 & 2.15 & 71.00 & -18.56 & 1.75 & 1.34 & 1.39 & 45.00 & -20.57 & 1.58 \\
\hline Brazil & 1.81 & 1.65 & 1.77 & 313.00 & -2.21 & 1.19 & 1.10 & 1.12 & 194.00 & -5.88 & 1.61 \\
\hline Chile & 2.62 & 2.32 & 2.18 & 29.00 & -16.79 & 1.90 & 1.80 & 1.42 & 18.00 & -25.26 & 1.61 \\
\hline Colombia $^{c}$ & 2.66 & 2.46 & 2.61 & 107.00 & -1.88 & 1.96 & 1.88 & 1.97 & 79.00 & 0.51 & 1.35 \\
\hline Costa Rica & 4.13 & 2.73 & 2.44 & 10.00 & -40.92 & 3.10 & 1.83 & 2.06 & 8.00 & -33.55 & 1.25 \\
\hline Cuba & 2.59 & 2.63 & 2.27 & 18.00 & -12.36 & 1.74 & 1.77 & 1.72 & 12.00 & -1.15 & 1.50 \\
\hline Dominican Republic ${ }^{d}$ & 1.08 & 0.77 & 0.85 & 7.00 & -21.30 & 0.71 & 0.70 & 0.68 & 6.00 & -4.23 & 1.17 \\
\hline Ecuador & 2.23 & 2.36 & 2.96 & 37.00 & 32.74 & 1.89 & 2.17 & 2.06 & 25.00 & 8.99 & 1.48 \\
\hline Mexico & 2.56 & 2.67 & 3.04 & 290.00 & 18.75 & 1.92 & 1.97 & 2.11 & 211.00 & 9.90 & 1.37 \\
\hline Paraguaye & 1.72 & 1.96 & 1.94 & 11.00 & 12.79 & 1.79 & 1.69 & 1.43 & 8.00 & -20.11 & 1.38 \\
\hline Uruguay $^{f}$ & 1.89 & 2.06 & 1.55 & 4.00 & -17.99 & 1.81 & 1.85 & 1.88 & 5.00 & 3.87 & 0.80 \\
\hline Venezuela ${ }^{g}$ & 2.65 & 2.59 & 2.48 & 62.00 & -6.42 & 1.91 & 1.89 & 2.03 & 49.00 & 6.28 & 1.27 \\
\hline
\end{tabular}

a $\mathrm{ASR}(\mathrm{W})$ : age-standardized death rates (World Population).

${ }^{b}$ Ratio Males/Females calculated from the average number of cases in each sex for the period 2000-2004.

c No data for 6 years: $1980-1984,2002$, and 2003.

d No data for 2 years: 1993 and 2002

e No data for 2 years: 1992 and 1993.

f No data for 3 years: 1991, 1992, and 2002.

g No data for 3 years: 1984, 1991, and 1995.

TABLE 3. Joinpoint regression analysis of leukemia mortality in children (truncated rates for 0-14 years of age) in 12 countries of Latin America, 1980-2004

\begin{tabular}{|c|c|c|c|c|c|c|c|c|c|c|}
\hline & \multicolumn{6}{|c|}{ Males } & \multicolumn{4}{|c|}{ Females } \\
\hline & \multicolumn{2}{|c|}{ Trend 1} & \multicolumn{2}{|c|}{ Trend 2} & \multicolumn{2}{|c|}{ Trend 3} & \multicolumn{2}{|c|}{ Trend 1} & \multicolumn{2}{|c|}{ Trend 2} \\
\hline & Years & $\begin{array}{c}\mathrm{APC}^{\mathrm{a}} \\
(95 \% \mathrm{Cl})\end{array}$ & Years & $\begin{array}{c}\text { APC } \\
(95 \% \mathrm{Cl})\end{array}$ & Years & $\begin{array}{c}\text { APC } \\
(95 \% \mathrm{Cl})\end{array}$ & Years & $\begin{array}{c}\mathrm{APC} \\
(95 \% \mathrm{Cl})\end{array}$ & Years & $\begin{array}{c}\mathrm{APC} \\
(95 \% \mathrm{Cl})\end{array}$ \\
\hline Argentina & 1980-2004 & $\begin{array}{c}-3.15^{\mathrm{b}} \\
(-3.93,-2.36)\end{array}$ & & $-^{c}$ & & - & 1980-2004 & $\begin{array}{c}-2.45^{\mathrm{b}} \\
(-3.07,-1.83)\end{array}$ & & - \\
\hline Brazil & 1980-2004 & $\begin{array}{c}-1.01^{\mathrm{b}} \\
(-1.46,-0.56)\end{array}$ & & - & & - & 1980-1995 & $\begin{array}{c}-1.60^{\mathrm{b}} \\
(-2.31,-0.88)\end{array}$ & 1996-2004 & $\begin{array}{c}1.34 \\
(-0.23,2.95)\end{array}$ \\
\hline Colombia & 1984-2004 & $\begin{array}{c}-0.37 \\
(-1.24,0.50)\end{array}$ & & - & & - & 1984-2004 & $\begin{array}{c}-0.30 \\
(-1.24,0.66)\end{array}$ & & - \\
\hline Costa Rica & 1980-2004 & $\begin{array}{c}-2.04^{b} \\
(-3.99,-0.05)\end{array}$ & & - & & - & 1980-2004 & $\begin{array}{c}-3.87^{\mathrm{b}} \\
(-5.61,-2.09)\end{array}$ & & - \\
\hline Cuba & 1980-2004 & $\begin{array}{c}-0.35 \\
(-1.36,0.67)\end{array}$ & & - & & - & 1980-2004 & $\begin{array}{c}-1.15^{b} \\
(-2.23,0.05)\end{array}$ & & - \\
\hline Mexico & 1980-1987 & $\begin{array}{c}3.31^{\mathrm{b}} \\
(1.68,4.96)\end{array}$ & 1988-1990 & $\begin{array}{c}-6.07 \\
(-16.59,5.77)\end{array}$ & 1991-2004 & $\begin{array}{c}1.73^{b} \\
(1.16,2.30)\end{array}$ & 1980-2004 & $\begin{array}{c}0.90^{\mathrm{b}} \\
(0.56,1.24)\end{array}$ & & - \\
\hline Paraguay & 1980-1998 & $\begin{array}{c}2.07^{b} \\
(0.40,3.76)\end{array}$ & 1999-2004 & $\begin{array}{c}-8,17^{b} \\
(-15.50,-0.20)\end{array}$ & & - & 1980-2004 & $\begin{array}{c}1.04 \\
(-1.38,3.51)\end{array}$ & & - \\
\hline Uruguay & 1980-2004 & $\begin{array}{c}-4.55^{\mathrm{b}} \\
(-7.32,-1.70)\end{array}$ & & - & & - & 1980-2004 & $\begin{array}{c}-4.64 \\
(-8.13,1.02)\end{array}$ & & - \\
\hline Venezuela & 1980-2004 & $\begin{array}{c}-0.24 \\
(-0.79,0.31)\end{array}$ & & - & & - & 1980-2004 & $\begin{array}{c}-0.89^{\mathrm{b}} \\
(-1.50,-0.28)\end{array}$ & & - \\
\hline
\end{tabular}

a Annual percentage change.

b Significantly different from $0(P<0.05)$.

c No data. 
TABLE 4. Joinpoint regression analysis of leukemia mortality in adolescents and young adults (truncated rates for 15-24 years of age) in 12 Latin America countries, 1980-2004

\begin{tabular}{|c|c|c|c|c|c|c|}
\hline \multirow[b]{3}{*}{ Country } & \multicolumn{4}{|c|}{ Male } & \multirow{2}{*}{\multicolumn{2}{|c|}{$\begin{array}{l}\text { Female } \\
\text { Trend } 1\end{array}$}} \\
\hline & \multicolumn{2}{|c|}{ Trend 1} & \multicolumn{2}{|c|}{ Trend 2} & & \\
\hline & Years & $\begin{array}{c}\text { APCa }^{\text {AP }} \\
(95 \% \mathrm{Cl})\end{array}$ & Years & $\begin{array}{c}\text { APC } \\
(95 \% \mathrm{Cl})\end{array}$ & Years & $\begin{array}{c}\text { APC } \\
(95 \% \mathrm{Cl})\end{array}$ \\
\hline Argentina & 1980-2004 & $\begin{array}{c}-0.97^{\mathrm{b}} \\
(-1.89,-0.04)\end{array}$ & $-^{c}$ & - & $1980-1985$ & $\begin{array}{c}-1.13^{\mathrm{b}} \\
(-2.24,-0.01)\end{array}$ \\
\hline Brazild $^{d}$ & $1980-1986$ & $\begin{array}{c}-3.64 \\
(-7.34,0.20)\end{array}$ & 1986-2004 & $\begin{array}{c}0.59 \\
(-0.16,1.34)\end{array}$ & 1980-2004 & $\begin{array}{c}-0.22 \\
(-0.72,0.27)\end{array}$ \\
\hline Chile & $1980-2004$ & $\begin{array}{c}-0.82 \\
(-1.70,0.06)\end{array}$ & - & - & 1980-2004 & $\begin{array}{c}-1.66 \\
(-3.60,0.31)\end{array}$ \\
\hline Colombia & 1984-2004 & $\begin{array}{c}0.25 \\
(-0.56,1.07)\end{array}$ & - & - & 1984-2004 & $\begin{array}{c}-0.74 \\
(-1.84,0.37)\end{array}$ \\
\hline Costa Rica & $1980-2004$ & $\begin{array}{c}-2.26^{b} \\
(-4.07,-0.43)\end{array}$ & - & - & 1980-2004 & $\begin{array}{c}-2.58 \\
(-5.95,0.90)\end{array}$ \\
\hline Cuba & 1980-2004 & $\begin{array}{c}-0.65 \\
(-1.63,0.34)\end{array}$ & - & - & 1980-2004 & $\begin{array}{c}-0.30 \\
(-1.66,1.07)\end{array}$ \\
\hline Dominican Republic & $1980-2004$ & $\begin{array}{c}-1.43 \\
(-3.34,0.52)\end{array}$ & - & - & 1980-2004 & $\begin{array}{c}-0.89 \\
(-4.66,3.04)\end{array}$ \\
\hline Ecuador & 1980-2004 & $\begin{array}{c}1.02 \\
(-0.14,2.19)\end{array}$ & - & - & 1980-2004 & $\begin{array}{c}0.53 \\
(-0.86,1.94)\end{array}$ \\
\hline Mexico & 1980-2004 & $\begin{array}{c}0.93^{b} \\
(0.57,1.30)\end{array}$ & - & - & 1980-2004 & $\begin{array}{c}0.42^{b} \\
(0.03,0.81)\end{array}$ \\
\hline Paraguay & $1980-2004$ & $\begin{array}{c}0.48 \\
(-1.84,2.86)\end{array}$ & - & - & 1980-2004 & $\begin{array}{c}0.33 \\
(-2.06,2.78)\end{array}$ \\
\hline Uruguay & $1980-2004$ & $\begin{array}{c}0.72 \\
(-1.69,3.18)\end{array}$ & - & - & 1980-2004 & $\begin{array}{c}-1.93 \\
(-4.93,1.17)\end{array}$ \\
\hline Venezuela & $1980-2004$ & $\begin{array}{c}-0.38 \\
(-0.92,0.16)\end{array}$ & - & - & 1980-2004 & $\begin{array}{c}0.05 \\
(-0.79,0.89)\end{array}$ \\
\hline
\end{tabular}

For AYA, mortality rates increased significantly in Mexico for both males and females. Significant downward trends were observed in Argentina for both males $(-0.97 \%$ annually; $95 \% \mathrm{CI}=$ -1.9 to -0.04$)$ and females (-1.13\% annually, $95 \% \mathrm{CI}=-2.2$ to -0.01$)$; and in Costa Rica for males only ( $-2.26 \%$ annually; $95 \% \mathrm{CI}=-4.1$ to -0.4$])$. For all other countries (Brazil, Chile, Colombia, Cuba, Dominican Republic, Ecuador, Paraguay, Uruguay, and Venezuela), no major changes in mortality rates occurred in the last two decades studied. However, all countries showed downward trends, except for males in Colombia and Uruguay, females in Venezuela, and both genders in Ecuador and Paraguay. These showed an upward trend with no statistical significance. In Brazil, a downward trend could be noted for males in 1980-1986 with no statistical significance, followed by an upward and similarly statistically non-significant trend for 1986-2004.

\section{DISCUSSION}

Although cancer is an uncommon diagnosis in AYA, in England it represents an appreciable health problem and an important disease-related cause of death among the population 15-24 years of age (13). In the United States, malignant neoplasm represents the fourth most common cause of death in this age group, accounting for $5.23 \%$ of all deaths (14). In addition, during the period 1973-1992, adolescents had the greatest increases in cancer incidence rates and the smallest mortality rate reductions among all age groups in Western Europe (15). The overall 5-year survival rate has been reported to be $77 \%$, ranging from $45 \%$ (acute leukemia) to 90\% (Hodgkin's lymphoma or germ cell tumors) $(16,17)$. Leukemia and lymphoma account for one-third of all cancer diagnoses among AYA in the United States $(4,16)$.

Among those 15-24 years of age in Latin America, leukemia is the first cancer-related cause of death (6). In recent decades, important changes in leukemia mortality have occurred all over the world. Mortality from childhood leukemia has shown a significant decline. More effective multidrug chemotherapy protocols, together with the introduction of various supportive measures to overcome toxicity, as well as improved diagnostic techniques for cancer treatment, have progressively become available, drastically improving the prognosis for this neoplasm (18).

Leukemia mortality for all ages has also shown decreases all over the world. A study conducted in China showed that from 1987-1999, there was a significant decrease in leukemia mortality in the age group 15-34 years of age, ranging from $1.1 \%$ for rural males to $3 \%$ for urban females (19). Nonetheless, for the age group 15-24 years of age, these declines in leukemia mortality rates have not been so significant. In Brazil, from 19802002 no statically significant changes 
were noted in leukemia mortality rates for the age group 15-19 years (20). In Western Europe, declines in leukemia mortality were smaller for this age group (50\%) than for the age group 0-14 years (60\%) during 1955-1995 (21). So, even if mortality cancer rates for AYA have fallen compared to those of adults, they have shown a much smaller improvement in survival when compared to mortality from cancer in children less than 15 years of age (4).

The present analysis indicates a significant upward trend in leukemia mortality among AYA and children in Mexico alone. Another study (22) found the same trend in Mexico, as well as in Ecuador, when analyzing leukemia mortality for all ages and truncated to 35-64 years of age during 1970-2000. Although, even if in Mexico there is an upward trend for leukemia mortality rates, rates remain relatively low compared to the rates of other countries around the world (23). Most of the other countries showed a decrease in leukemia mortality rates among AYA, but only Argentina and Costa Rica presented statistically significant declines for this group; whereas, in most countries, leukemia mortality among children was on a significant downward trend.

For all countries, the male to female ratios were similar. In 1995, some declines in cancer mortality for all ages in Latin America were observed (24), but rates were still substantially higher than in North America (especially in Mexico, where rates were already growing at that time). However, a study conducted in 2005 (22) found that leukemia mortality in Latin American countries was slightly lower than in Canada and the United States. Rates for women in Latin America were comparable to those of women in North America.

Trends identified in this article show that leukemia mortality patterns in Latin America are similar to those observed in other developed areas of the world, such as England and the United States (4, 25). It is possible that the results found in Mexico were also influenced by the improved

1. Belizan JM, Cafferata ML, Belizan M, Althabe F. Health inequality in Latin America. Lancet. 2007;370(9599):1599-600.

2. Levi F, La VC, Negri E, Lucchini F. Childhood cancer mortality in Europe, 1955-1995. Eur J Cancer. 2001;37(6):785-809. accuracy of diagnosis and certification. Nonetheless, this report shows that leukemia outcomes in AYA remain poorer than those expected for children less than 15 years of age. Differences in survival between AYA and younger children are thought to reflect less appropriate treatment protocols for this age group, as well as some differences in the biological characteristics of the disease, such as the translocation $t(12,19)$ which occurs in about one-quarter of childhood B-cell Acute Lymphoblastic Leukemia and is only observed in approximately $3 \%$ of adults cases (26). Treatment protocols specifically for AYA are not well defined, and they are usually treated either in pediatric or adult wards, not being recognized as a distinct group of patients with specific physical and psychological needs.

Another important issue pertaining to cancer mortality in Latin America is the health care system. The geographic area analyzed is very diverse and has a variety of different health care systems. However, the countries studied have social inequality in common, which infers that most (except Cuba) provide very unequal access to the public health system. In many countries of Latin America, even if effective international treatment protocols for leukemia are available, access to medical care may be limited. Such disease treatment requires complex management and is provided exclusively by specialized centers. The specialized oncology centers are located in big metropolitan cities, where patients usually need a referral from the primary physician and/or a diagnostic test to be able to obtain treatment. These specialized centers receive patients for oncological treatment from the whole state, which generates an overwhelming influx of patients. The primary health care staff is responsible for recognizing the presentation of an oncological disease, and then correctly managing patients in the initial stages of the disease, when modern treatment can be very effective.

Latin America has a very heterogeneous distribution of wealth and health

\section{REFERENCES}

3. Seibel NL. Treatment of acute lymphoblastic leukemia in children and adolescents: peaks and pitfalls. Hematology Am Soc Hematol Educ Program, volume 2008:374-80.

4. Pearce MS, Parker L, Windebank KP, Cotterill SJ, Craft AW. Cancer in adolescents and care, as mentioned before. Because specialized oncological centers are not numerous, and most of them are situated in urban and wealthier areas, late diagnosis is a reality for the population living outside these areas. National-level studies are needed to further examine these differences.

The heterogeneity of the data quality and missing data for some countries are a limitation to the results and need to be considered for all conclusions. However, the total population used in this research represents almost all of the population of Latin America (87.1\%).

In conclusion, leukemia mortality trends among children and AYA in Latin America indicate a decrease in most countries comparable to the trends observed in higher-income areas, such as Western Europe, the United States, and the United Kingdom. Regarding the rates for AYA found in this study, it can be inferred that they are similar to what is being observed in other parts of the world, including developed countries. Rates among AYA are declining, but show a less significant decrease than rates among children. The study results point to a global need for further advances, especially for AYA, similar to those made by childhood leukemia therapeutic protocols.

Additionally, the social inequalities observed in Latin America (1) dramatically affect the health care system, and combined with the poverty of the area, present a very complex problem with no easy answer. To improve leukemia medical care for AYA, and specifically, access to advanced treatment protocols, economic and social improvements are fundamental, perhaps through investment in basic infrastructure, including the health care network. Additional specialized oncological centers, improved primary health care, and better trained health professionals are needed for AYA in the lower-resource areas of Latin America. Lastly, special attention should be paid to leukemia in Mexico, where significant upward trends were observed. young adults aged 15-24 years: a report from the North of England young person's malignant disease registry, UK. Pediatr Blood Cancer. 2005;45(5):687-93.

5. United Nations expert group meeting on social and economic implications of changing 
population age structure. The diversity of changing population age structure. Mexico City: United Nations; 2005.

6. Stiller CA. International patterns of cancer incidence in adolescents. Cancer Treat Rev. 2007;33(7):631-45.

7. World Health Organization. Mortality Database 2010. Available from: http:/ / www.who. int/healthinfo/morttables/en/. Accessed on 25 February 2010.

8. World Health Organization. International classification of diseases. 9th revision. Geneva: WHO; 1977.

9. World Health Organization. International classification of diseases. 10th revision. Geneva: WHO; 1992.

10. United Nations Population Division. World population prospects. 2008 revision. Available from: http://data.un.org/Data.aspx?d= PopDiv\&f=variableID\%3a12. Accessed on 25 February 2010.

11. Boyle P, Parkin DM. Statistical methods for registries. In: Jensen OM, Parkin DM, Maclennan $\mathrm{R}$, Muir CS, Skeet RG, eds. Cancer registration principles and methods. Lyon: International Agency for Research on Cancer; 1991. Pp. 126-58.

12. Kim HJ, Fay MP, Feuer EJ, Midthune DN. Permutation tests for joinpoint regression with applications to cancer rates. Stat Med. 2000; 19(3):335-51.

13. Alston RD, Rowan S, Eden TO, Moran A, Birch JM. Cancer incidence patterns by region and socioeconomic deprivation in teenagers and young adults in England. Br J Cancer. 2007;96(11):1760-6.

14. United States Centers for Disease Control and Prevention. National Vital Statistics System. National Vital Statistics Report. Washington: CDC; 2005. [CDC/NVS/2005.17]

15. Bleyer WA, Tejeda H, Murphy SB, Robison LL, Ross JA, Pollock BH, et al. National cancer clinical trials: children have equal access; adolescents do not. J Adolesc Health. 1997;21(6): 366-73.

16. Albritton K, Bleyer WA. The management of cancer in the older adolescent. Eur J Cancer. 2003;39(18):2584-99.

17. Evan EE, Zeltzer LK. Psychosocial dimensions of cancer in adolescents and young adults. Cancer. 2006;107(7 Suppl):1663-71.

18. Moghrabi A, Levy DE, Asselin B, Barr R, Clavell L, Hurwitz C, et al. Results of the Dana-Farber Cancer Institute ALL Consortium Protocol 95-01 for children with acute lymphoblastic leukemia. Blood. 2007;109(3): 896-904.

19. Yang L, Parkin DM, Li L, Chen Y. Time trends in cancer mortality in China: 1987-1999. Int J Cancer. 2003;106(5):771-83.

20. Ribeiro KB, Lopes LF, de CB. Trends in childhood leukemia mortality in Brazil and correlation with social inequalities. Cancer. 2007; 110(8):1823-31.

21. Terracini B, Coebergh JW, Gatta G, Magnani C, Stiller C, Verdecchia A, et al. Childhood cancer survival in Europe: an overview. Eur J Cancer. 2001;37(6):810-6.

22. Bosetti C, Malvezzi M, Chatenoud L, Negri E, Levi F, La VC. Trends in cancer mortality in the Americas, 1970-2000. Ann Oncol. 2005; 16(3):489-511.

23. Malvezzi M, Bosetti C, Chatenoud L, Rodriguez T, Levi F, Negri E, et al. Trends in cancer mortality in Mexico, 1970-1999. Ann Oncol. 2004;15(11):1712-8.

24. Levi F, La VC, Lucchini F, Negri E, Boyle P. Patterns of childhood cancer mortality: America, Asia and Oceania. Eur J Cancer. 1995; 31A(5):771-82.

25. Wu XC, Chen VW, Steele B, Roffers S, Klotz $\mathrm{JB}$, Correa $\mathrm{CN}$, et al. Cancer incidence in adolescents and young adults in the United States, 1992-1997. J Adolesc Health. 2003; 32(6):405-15.

26. Aguiar RC, Sohal J, van RF, Carapeti $\mathrm{M}$ Franklin IM, Goldstone AH, et al. TELAML1 fusion in acute lymphoblastic leukaemia of adults. M.R.C. Adult Leukaemia Working Party. Br J Haematol. 1996;95(4):673-7.

Manuscript received on 2 March 2010. Revised version accepted for publication on 19 August 2010.

RESUMEN Objetivo. Describir y comparar las tendencias de la mortalidad por leucemia en los niños (entre los 0 y los 14 años de edad) y en los adolescentes y adultos jóvenes (entre los 15 y los 24 años de edad) en 12 países de América Latina entre 1980 y el 2004.

\section{Tendencias de la mortalidad por leucemia en niños, adolescentes y adultos jóvenes en América Latina}

Métodos. Se analizaron los datos sobre mortalidad de la base de datos de la Organización Mundial de la Salud mediante un modelo de regresión joinpoint, con el fin de detectar los cambios significativos en la tasa de mortalidad con el transcurso del tiempo y calcular la variación porcentual por año.

Resultados. La leucemia ocupa el primer lugar entre las causas de muerte por cáncer en los niños y en los adolescentes y adultos jóvenes en América Latina. En los niños, las variaciones porcentuales mundiales indicaron un aumento en las tasas en ambos sexos en Colombia, Ecuador y México, con cifras considerablemente más altas en México. En los adolescentes y adultos jóvenes, se observaron aumentos significativos en ambos sexos en México; Ecuador presentó un ligero aumento en ambos sexos; y en Colombia y Uruguay solo se observó un incremento en las mujeres. Se encontraron tendencias decrecientes en Argentina en ambos sexos y en Costa Rica solo en los hombres. No se observaron variaciones importantes en los demás países analizados. Conclusiones. Las tasas de mortalidad por leucemia en los adolescentes y adultos jóvenes están disminuyendo, pero en forma menos marcada que la disminución observada en los niños. Los resultados del estudio ponen de manifiesto la necesidad mundial de alcanzar mayores progresos, en especial en cuanto a los adolescentes y los adultos jóvenes, que sean equivalentes a los obtenidos con los protocolos terapéuticos contra la leucemia en la niñez. Además, a pesar de que existen centros oncológicos especializados en la mayoría de los países de América Latina, a menudo son inaccesibles. Se debe prestar especial atención a México, debido al aumento considerable de sus tasas de mortalidad.

Palabras clave Leucemia; niño; adulto joven; adolescente; América Latina. 